\title{
Geir Skeie
}

Stockholm Universitet/Universitetet i Stavanger

\section{Mangfoldets utfordringer og muligheter sett gjennom religionsdidaktisk forskning. Et nordisk overblikk}

DOI: http://dx.doi.org/10.5617/adno.4832

\section{Sammendrag}

Artikkelen gir et overblikk over hvordan nyere nordisk religionsdidaktisk forskning har ncermet seg spørsmål om mangfoldets utfordringer og muligheter. Overblikket baseres på analyse av doktoravhandlinger, noen forskningsprosjekter og en del artikler. Det spørres om hvordan forskningen beskriver religions- og livssynsmangfoldet, hvilke religionsdidaktiske utfordringer den mener mangfoldet reiser og hvilke strategier lererne kan ta i bruk $i$ arbeid med faget i klasserommet? Analysen viser at forskningen er omfattende og økende, men omfanget varierer mellom de nordiske landene. Den aktuelle forskningen bidrar i betydelig grad til å forstå og problematisere religionsundervisningens plass og rolle $i$ et samfunn som preges av okt religions- og livssynsmangfold, og til å forstå at forskningsfeltet er blitt til i et samspill mellom ulike akademiske disipliner, og dessuten mellom politikk, forskning og praksis. Resultatene fra forskningen bidrar først og fremst til a belyse mangfoldets omfang og kompleksitet, samt at det i varierende grad fanges opp av lcereplaner og undervisning. Det er mindre av forskning som belyser læererarbeidet, lcreprosesser og resultater av undervisningen. Forskningen viser også at religions- og livssynsmangfold må ses som en viktig del av forutsetningene for undervisning og lering $i$ alle fag, og i religions- og livssynsfagene er den i dag en selvsagt forutsetning, uavhengig av hvordan disse er organisert $i$ de ulike landene.

Nøkkelord: mangfold, flerkultur, religionsundervisning, forskning, 


\title{
How does recent Nordic religious education research address the challenges and possibilities of religious and world view diversity?
}

\begin{abstract}
The article gives an overview of how recent Nordic religious education research has approached issues related to the challenges and possibilities that religious and worldview diversity pose to education. The emphasis is on PhDs, a few research projects and articles. How does the research describe diversity, which challenges are pointed out and what strategies can teachers in the classroom employ. The analysis shows that there is a growing research mainly in Norway, Sweden and Finland, compared with Denmark and Iceland. The research investigated contributes mainly to new knowledge about the distribution and complexity of diversity in classrooms and to some extent to increased knowledge about how the diversity is dealt with in classrooms and curricula. It is also shown that this diversity is a challenge to the whole school, not only religious education. Less research is directed towards issues of teaching and learning and the effects of this.
\end{abstract}

Keywords: diversity, intercultural, religious education, research

\section{Innledning og bakgrunn}

Debatten om religion i skolen har endret seg i alle de nordiske landene i løpet av de siste tiårene. Mens dette tidligere handlet mye om kristendommens plass og rolle, er det dominerende temaet i dag hvordan skolen bør forholde seg til religiøst og livssynsmessig mangfold. Samtidig henger disse to hovedtemaene uløselig sammen. Et tydelig eksempel på dette er de siste årenes debatt om hvorvidt det norske grunnskolefaget «Religion livssyn og etikk», forkortet til RLE, skulle endre navn til «Kristendom, religion, livssyn og etikk», noe som da også skjedde i 2015. Samtidig ble det formalisert at faginnhold om kristendom skulle ha omtrent $50 \%$ av undervisningstiden. Argumentasjonen for dette var at kristendommen er den dominerende religionen i Norge og viktig for å forstå norsk kultur, mens et viktig motargument var at dette ikke avspeilte mangfoldet i norsk kultur på en god måte (Døving, 2016). Ettersom den økende vekten på religions- og livsynsmangfold forbindes med innvandring, så aktualiserer slike debatter den rollen skolen skal ha $\mathrm{i}$ integreringspolitikken og religionsundervisningen. Hvor synlig skal samfunnets kulturelle og religiøse mangfold være? Hvor viktig er det for nasjonens selvforståelse?

I Norge har det vært hevdet at religionsfaget er det av skolefagene som bidrar mest til å synliggjøre kulturelt mangfold i planer og praksis (Dessingué, 2016; 
Nielsen, 2012). Den offentlige debatten om religionsundervisning, i læreplaner og undervisningspraksis, vier nå mer oppmerksomhet til mangfold. Denne artikkelen spør om dette gjenspeiles i religionsdidaktisk forskning, slik at forskningen kan bidra med kunnskap i utformingen av policy og praksis.

Konteksten er de nordiske landene, hvor mangfold har stått på den utdanningspolitiske og religionsdidaktiske dagordenen i mange år. Sverige var først ute med å endre læreplaner i retning av et ikke-konfesjonelt religionsfag på slutten av 1960-tallet, da primært med bakgrunn i det økte mangfoldet som sekulariseringen skapte. Faget ble elevorientert og tok opp livsspørsmål i tillegg til ulike religioner og livssyn (Osbeck \& Skeie 2014). Også i Danmark ble religionsfaget frikoblet fra sin kirkelige forankring på 1970-tallet, og inkluderte undervisning om religioner og livssyn, men beholdt navnet «Kristendomkundskab» og en allmenn fritaksrett (Buckardt, 2014). Den norske religionsundervisningen ble prinsipielt løsrevet fra kirkens dåpsopplæring på 1960-tallet, men beholdt et konfesjonelt preg enda tre tiår. Underveis ble det etablert en parallellmodell, der faget «Livsynskunnskap» ble et viktig alternativ mange steder fra 1974. Først i 1997 fikk man et allment religions- og livssynsfag uten generell fritaksrett, og dette har vært regelen siden, tross en rekke justeringer av læreplan og regelverk (Skeie \& Bråten, 2014). Island hadde et kristendomsorientert religionsfag fra 1974, inntil de i 2013 la all undervisning i religion inn som del av et bredt samfunnsfag, der også historie og geografi var inkludert (Gunnarsson 2014). Så er det Finland, som har hatt en modell med konfesjonelt preg hele tiden. Imidlertid førte økende mangfold til behov for tilpasninger, og fra 2004 har finnene tilbudt undervisningsløp knyttet til «elevenes egen religion», med i alt 13 parallelle læreplaner (Ubani \& Tirri, 2014).

Samlet sett må man derfor kunne si at de nordiske landene stort sett har forlatt det man tradisjonelt har kalt en «konfesjonell» modell for religionsundervisning. Selv den finske løsningen kalles ikke konfesjonell, fordi religionssamfunnene ikke har noen sentral rolle i arbeidet med læreplaner, lærerutdanning eller undervisningspraksis. Det er i stedet staten som står for alt dette. Likevel har økt mangfold ført til ulike læreplanløsninger. Utviklingen bort fra tidligere tiders konfesjonelle modeller har nok gjort det lettere for forskningen å se at man arbeider med liknende problemer i ulike land. Denne artikkelen spør hva slags bidrag religionsdidaktisk forskning har gitt når det gjelder å forstå og forbedre planer og praksis. Mer presist reises følgende problemstillinger:

- Hvordan beskrives religions- og livssynsmangfoldet?

- Hvilke religionsdidaktiske utfordringer reiser mangfoldet?

- Hvilke strategier foreslås for lærerne i arbeid med faget i klasserommet? 
Spørsmålene behandles med en noe større vekt på den norske situasjonen, som forfatteren kjenner best. Jeg starter imidlertid med å si noe om hvilken rolle «mangfold» spiller i aktuell utdanningspolitikk, og går deretter inn på utviklingen av religionsdidaktisk forskning.

\section{Mangfold som utfordring og mulighet i utdanningspolitikk}

Det temaet som står i sentrum for denne artikkelen, er altså religiøst og livssynsmessig mangfold i skolen og dens religionsundervisning. Det er imidlertid ikke uproblematisk å bruke mangfoldsbegrepet fordi mange oppfatter det som upresist, og fordi det er involvert i mange diskurser som hver for seg reiser viktige spørsmål (Nyléhn \& Biseth, 2015; Westrheim \& Tolo, 2014). Samtidig er begrepet så mye brukt at det vanskelig kan unngås, særlig i utdanningssammenheng. Som eksempel kan vi se på den rolle som «mangfold» spiller i aktuell norsk utdanningspolitikk og hvordan religion og livssyn håndteres som del av dette. Stortingsmelding 20 (2012-2013) viser at man i hovedsak bruker begrepet «mangfold» på to måter som også kan spores i seinere utdanningspolitiske dokumenter. Den ene er primært beskrivende, og viser til at elever er ulike når det gjelder evner og en rekke andre forutsetninger. Den andre er primært normativ, og understreker at mangfold er positivt i seg selv, og at det er en ressurs i læringsarbeidet. Samtidig er disse to perspektivene flere steder vevd sammen syntaktisk på en måte som gjør dem vanskelig å holde fra hverandre:

«Elever og lærlinger har ulike evner, ulike kunnskaper og ulik sosial og kulturell bakgrunn. Mangfoldet gir utfordringer, men er også en ressurs som gir mulighet til å lære av forskjellighet og til å fremme gjensidig respekt og toleranse mellom mennesker med ulik bakgrunn og levesett. Samene og de nasjonale minoritetene er en viktig del av mangfoldet i Norge. Skolen skal ha rom for alle uten å skille etter evner, kjønn, funksjonsevne eller bakgrunn.»

(Stortingsmelding 20 (2012-2013), s. 11)

Det er ikke noe klart skille mellom de spørsmål som dreier seg om beskrivelsen av mangfoldet og dem som dreier seg om hvordan man vil forholde seg til det, praktisk og normativt. Dermed blir meldingen uklar når det gjelder hva slags utfordringer som mangfoldet kan innebære. Spesielt tydelig blir dette i måten religion og livssyn omtales på. Selv om meldingen utvilsomt ser religions- og livssynsforskjeller som del av det brede mangfoldsbegrepet som den opererer med, så knyttes dette først og fremst til skolens formål. Når konkrete tiltak nevnes som svar på de utfordringene som mangfoldet reiser, havner religion og livssyn i bakgrunnen. I stedet er det samfunnsfaget som har fått særskilt omtale, med tydelig vekt på dets bidrag til å møte mangfoldets utfordringer. 
Ved å knytte religions- og livssynsmangfold utelukkende til formålsparagrafen tildekkes flere problematiske og komplekse sider ved tematikken, slik også andre har pekt på (Westrheim \& Hagatun, 2015). Det kan se ut som man oppfatter utfordringene primært som juridiske, noe som forsterkes av stortingskomiteen som $\mathrm{i}$ sin behandling av den samme stortingsmeldingen peker på religions- og livssynsmangfoldet som særlig viktig, men legger hovedvekten på at mulige konflikter på religions- og livssynfeltet er løst gjennom den nye formålsparagrafen ved «at den kristne og humanistiske kultur- og verditradisjonen fortsatt skal ha særlig vekt i skolens arbeid, samtidig som paragrafen også løfter det flerkulturelle og flerreligiøse tydeligere fram som en viktig del av skolens arbeid» (Innst. 432 S (2012-2013), s. 10).

Det kan altså se ut som om religions- og livssynsmangfold primært knyttes til skolens overordnede formål og grunnlag gjennom formålsparagrafen, og der gis en positiv status. I tillegg spiller det en rolle som del av de mange og ulike forutsetninger som elever har og som skal tas hensyn til for å få et godt læringsmiljø. Det som befinner seg utenfor synsfeltet i denne stortingsmeldingen, er imidlertid hvordan det faglige kunnskapsinnholdet i skolens religions- og livssynsundervisning kan bidra til kompetanse og kvalifisering.

Religionsdidaktiske forskere har interessert seg for alle de tre aspektene ved mangfold som er nevnt ovenfor: formålsdiskusjonen, situasjonen for elever med ulik religions- og livsynsbakgrunn i skolen og undervisning og læring i religions- og livssynsfaget. Alle disse tre dimensjonene er gjenkjennbare også i andre nordiske land, og er blitt forsket på.

\section{Religionsdidaktisk forskning og mangfold}

Tidligere var fagområdet religionsdidaktikk knyttet til teologiske fagmiljøer i Norden, under betegnelsen «religionspedagogikk». En viktig historisk bakgrunn er den vekt som de lutherske statskirkene har lagt på pedagogisk virksomhet, og som gjorde at skolesystemet i det meste av Norden ble utviklet som kirkeskole på 1700-tallet, med konfirmasjon som «eksamen». Med sekulariseringen ble kirkenes innflytelse over skolen etter hvert begrensa til kristendomsundervisningen, som etter hvert mistet mer og mer av sin konfesjonelle forankring (Algotsson, 1975; Skinningsrud, 2012). I forlengelsen av dette kom også en skolerelatert religionspedagogikk, drevet fram av individuelle teologiske forskere som særlig interesserte seg for historiske eller prinsipielle sider ved religionsundervisningen. Derfor var religionspedagogikkens forankring i vitenskapelige fagmiljøer ved nordiske universiteter lenge avhengig av enkeltpersoners interesse og mulighet for fri forskning. 
Parallelt og delvis overlappende med denne teologisk pregede forskningstradisjonen vokste det også fram en religionsdidaktisk forskning som var påvirket av den fagdidaktiske «bølge» som gjorde seg gjeldende fra 1970tallet innenfor lærerutdanningsmiljøer i de nordiske land (Ålvik, 1974). Det skjedde etter hvert en bevisst vitenskapeliggjøring av fagdidaktisk forskning, der forskere med ulik fagbakgrunn utviklet et begrepsapparat (Nielsen, 1998). Finansieringen av fagdidaktisk forskning ble styrket i flere land, men fortsatt kan forskningsfeltet oppfattes som nytt (Ongstad, 2006, 2012, 2017). Som del av disse prosessene begynte «religionsdidaktikk» å bli tatt i bruk som en mer skoleorientert betegnelse på fagfeltet fra 1990-tallet, og har i dag mange steder avløst «religionspedagogikk» (Bråten, 2014). Denne utviklingen skjedde samtidig som migrasjon og kulturelt mangfold ble stadig mer vektlagt som forskningsmessige utfordringer, også i Norge (Engen, 1990, 1993). Komparative studier har vist at nordiske religionspedagoger og religionsdidaktikere tidlig fanget opp dette, ikke minst på grunn av kontakten med England, hvor religions og livssynsmangfold hadde vært på dagsordenen lenger (Alberts, 2007; Bråten, 2009; Bugge \& Johannessen, 1974). Særlig utover på 1980-tallet, styrket av den voksende fagdidaktikkbølgen, ble mangfold noe som religionsdidaktisk forskning tok fatt i, blant annet gjennom innsatsen til de få som også hadde vært pionerer i arbeidet med undervisning om ikke-kristne religioner (Østberg, 1998).

Forskningsoversiktene fra de nordiske religionspedagogiske forskningskonferansene viser at så sent som i 1993 var religions- og livssynsmangfold fortsatt bare en mindre sentral del. Den store bredden av temaer kan imidlertid tolkes som at man var inne i en brytningstid. Både nyreligiøsitet og verdensreligioner ble tatt opp på forskningskonferansene, samtidig som historisk, utviklingspsykologisk og kristendomsorientert didaktisk forskning fortsatt var tydelig representert. Det var på denne tida ikke alltid et klart skille mellom kirkelige eller skolerelaterte sammenhenger. I 1999 var situasjonen endret, søkelyset på mangfold dominerte både hovedforedrag, forskningspapers og nasjonale forskningsrapporter (Gunnarsson, 1999). Samtidig fikk konferansene en mer profesjonell form, og ble fra 2005 for første gang organisert som profesjonelle engelskspråklige forskerkonferanser (Tirri, 2006). Konferansene arrangeres hvert annet år, og har fortsatt mangfold som et sentralt tema. Fra 2015 ble de baltiske landene formelt inkludert (Schihalejev, Sporre, Skeie, Gunnarsson, \& Räsänen, 2016).

\section{Metode og materiale i undersøkelsen}

Den følgende diskusjonen skal si noe om hvor nordisk religionsdidaktisk forskning står i dag. Som bakgrunn brukes en del utvalgte publikasjoner fra de siste ti årene, og mitt søkelys er på mangfold. Mangfoldsutfordringer knyttet til migrasjon dukket opp som en erkjent utfordring for skolen i de nordiske landene 
på noe ulik tid,. Først i Sverige, deretter i Norge og Danmark utover 1970- og 80-tallet, og så på 90-tallet i Finland og på Island. Publikasjonene som utgjør materialet her, er utgitt etter dette, og har fanget opp denne utviklingen. Det har ikke vært mulig å dekke bredden av religionsdidaktisk forskning. En rekke relevante og sentrale bidrag er ikke tatt med, og det er mange forskere på feltet som ikke er nevnt. Likevel har det vært et mål å formidle et inntrykk av noen viktige trekk ved nordisk forskning. Med «nordisk forskning» menes her forskning utført av forskere som virker i Norden. Bidragene er begrenset til det som er tilgjengelig på engelsk eller skandinaviske språk.

Det har vært et ønske å fange opp en representativ gruppe forskere som selv oppfatter seg som religionsdidaktikere, og som har vært aktive i de siste årene. For å bidra til dette har jeg inkludert noen samlepublikasjoner fra de nordiske religionsdidaktiske forskerkonferanser og fra et aktuelt oversiktsverk. Det siste gjelder den presentasjonen av religionsundervisning i de nordiske landene som kom i en europeisk bokserie i 2014 (Rothgangel, Jackson, Jäggle, \& Skeie, 2014). Boka har avsnitt for hvert land og handler om grunnskolens undervisning og rammebetingelser for denne, læreplaner, juridiske forhold og lærerutdanning. Empirisk forskning er belyst, og det er et eget avsnitt om religiøst mangfold. Liknende og delvis overlappende oversikter finnes også andre steder (Davis \& Miroshnikova, 2013).

For å få fram resultater fra ferske forskningsartikler, har jeg valgt religionsdidaktiske artikler i et nordisk fagdidaktisk tidsskrift, Nordidactica. Tidsskriftet ble startet i 2011 og fokuserer på humanioras og samfunnsfagenes didaktikk. Alle nummerne, inkludert 2017/1, er undersøkt her. Her finnes totalt 103 artikler, hvorav 30 innholdsmessig kan knyttes til religionsdidaktikk. Nummer 2015/2 og 2017/1 er temanummer med søkelys på religionsdidaktikk, og halvparten av artiklene står i disse, i tillegg til egne lederartikler (Bråten, 2015a; Osbeck \& Buchardt, 2017). Jeg har også plukket ut den nyeste religionsdidaktiske doktorgradsavhandlingen fra hvert av de nordiske landene som tar opp temaer som er relevante for artikkelens problemstilling.

Et særlig forbehold gjelder islandsk og dansk religionsdidaktisk forskning. Begge steder har forskningen på dette feltet vært begrenset i mange år. På Island skyldes det først og fremst ressurser og at miljøene har vært små, mens i Danmark pekes det også på strukturelle endringer i høyere utdanning, som har svekket muligheter for forskning i tilknytning til lærerutdanningene (Buchardt 2014, s. 65f). Dette har ført til at det materialet som er undersøkt i denne artikkelen, i praksis presenterer arbeider fra en forsker fra hvert av de to landene, og deres perspektiver blir dermed særlig tydelige. Dette innebærer en viss ensidighet i undersøkelsens verdi for disse to landene. Resultatet er følgende materiale, sortert etter hvilket land forskeren arbeider i og etter hvilke publikasjonskanaler de ulike forskningsbidragene er hentet fra: 


\begin{tabular}{|c|c|c|c|c|c|}
\hline $\begin{array}{l}\text { Land } \\
\text { Publikasjoner }\end{array}$ & Danmark & Finland & Island & Sverige & Norge \\
\hline $\begin{array}{l}\text { Gunnarsson, } \\
1999\end{array}$ & \multirow{4}{*}{\multicolumn{5}{|c|}{$\begin{array}{l}\text { Disse publikasjonene er oversiktsmessig behandlet for å få fram et bilde av hvordan } \\
\text { mangfold er håndtert på de ulike konferansene, for gjennom dét å formidle et } \\
\text { inntrykk av hvordan det nordiske forskerfellesskapet forholder seg til de aspekter } \\
\text { ved tematikken som er tatt opp her. I en del tilfeller er det likevel henvist til } \\
\text { enkeltbidrag, for å lette tilgangen til materialet som er brukt. }\end{array}$}} \\
\hline Tirri, 2006 & & & & & \\
\hline Skeie, 2009 & & & & & \\
\hline $\begin{array}{lr}\text { Sporre } & \& \\
\text { Mannberg, } 2010\end{array}$ & & & & & \\
\hline $\begin{array}{l}\text { Oversiktsartikler } \\
\text { for de ulike land }\end{array}$ & $\begin{array}{l}\text { Buchardt, } \\
2014\end{array}$ & $\begin{array}{l}\text { Ubani \& Tirri, } \\
2014\end{array}$ & \begin{tabular}{|l|} 
Gunnarsson, \\
2014 \\
\end{tabular} & $\begin{array}{l}\text { Osbeck \& } \\
\text { Skeie, } 2014\end{array}$ & $\begin{array}{l}\begin{array}{l}\text { Skeie \& Bråten, } \\
2014\end{array} \\
\end{array}$ \\
\hline $\begin{array}{l}\text { Nordidactica - } \\
\text { alle nummer } \\
2011-2017 .\end{array}$ & $\begin{array}{l}\text { Buchardt, } \\
2017 \\
\text { Hobel, } \\
2013\end{array}$ & $\begin{array}{l}\text { Björkgren, } \\
\text { Gullberg, \& } \\
\text { Hilli, 2014 } \\
\text { Kallioniemi \& } \\
\text { Matilainen, } \\
2011 \\
\text { Ubani, } 2017 \\
\text { Ubani, } \\
\text { Kallioniemi, \& } \\
\text { Poulter, 2015 } \\
\text { Zilliacus, } 2013\end{array}$ & $\begin{array}{l}\text { Gunnarsson, } \\
2017 \\
\text { Gunnarsson, } \\
\text { Finnbogason, } \\
\text { Ragnarsdóttir } \\
\text { \& } \\
\text { Jónsdóttir, } \\
2015\end{array}$ & $\begin{array}{l}\text { Brömssen, } \\
\text { 2013a og } \\
\text { 2013b } \\
\text { Franck, } 2014 \\
\text { Hartman, } 2017 \\
\text { Hylén, 2012 } \\
\text { Osbeck, } 2014 \\
\text { og 2017 }\end{array}$ & $\begin{array}{l}\text { Bråten, 2015b } \\
\text { Duesund, } 2013 \\
\text { Haakedal, 2015 } \\
\text { Johannessen, } \\
2014 \\
\text { Krupka, } 2017 \\
\text { Lied \& Bakke, } \\
2013 \\
\text { Lippe, } 2011 \\
\text { Nicolaisen, } 2013 \\
\text { og 2015 } \\
\text { Skeie, } 2017 \\
\text { Vestøl, 2016 }\end{array}$ \\
\hline Antall artikler: & 2 & 5 & 2 & 7 & 11 \\
\hline $\begin{array}{l}\text { Nyeste relevante } \\
\text { avhandlinger }\end{array}$ & $\begin{array}{l}\text { Buchardt, } \\
2008\end{array}$ & Zilliacus, 2014 & $\begin{array}{l}\text { Gunnarsson, } \\
2008\end{array}$ & $\begin{array}{l}\text { Kittelmann } \\
\text { Flensner, } 2015\end{array}$ & $\begin{array}{l}\text { Johannessen, } \\
2015\end{array}$ \\
\hline
\end{tabular}

\section{Hvordan beskrives religions- og livssynsmangfoldet i forskningen?}

I empiriske bidrag fra de nordiske konferansene finnes det eksempler på hvordan mangfold beskrives gjennom undersøkelser av elever med bakgrunn fra bestemte religiøse grupper, som også innbyrdes gjerne presenteres som sammensatte (Birkedal om unge og kirkereligion og Duesund om tyrkiske muslimer i Gunnarsson 1999; Hella om lutherske kristne i Tirri, 2006; Holm, Nokelainen og Triiri om lutherske elever og Nicolaisen om hindu-barn i Skeie, 2009). Videre er det bidrag som ikke undersøker bestemte grupper, men som arbeider empirisk ved å se på mer allmene sider av barn og unges (Eriksson, Frangén og Gunnarsson i Gunnarsson 1999); Vermeer og Ubani i Tirri 2006; Gunnarsson og Ubani i Skeie 2009). Empiriske studier ser også på klasserommet og læreres og elevers holdninger (Westerberg, Räsänen og Berglund i Tirri 1999; Lied, Lyhykäinen, Olsson og Tirri i Skeie 2009) Den tallmessig mest dominerende typen bidrag har et mer teoretisk preg, og mange av disse drøfter problemstillinger av normativ og prinsipiell karakter, med vekt på mangfoldsutfordringer. Her er også mange av hovedforedragene inkludert (Jackson, Skeie, Buchardt, Wiedel og Østberg i Gunnarsson 1999; Wright, Niemi, Engedal, Kotila og Skeie i Tirri, 2006; Jackson, Heimbrock, Osbeck, Sporre og Fuglseth i Skeie 2009; Jozsa, Arnot, Sporre, Zinn \& Keet og Valk i 
Sporre og Mannberg 2010). Det synes å være et gjennomgående trekk at religions- og livssynsmangfold oppfattes som empirisk komplekst, og at de teoretiske bidragene følger opp gjennom å drive begrepsmessig refleksjon basert på denne kompleksiteten. Referansene i mange av bidragene viser at man ikke minst i de empiriske bidragene henter impulser fra annen forskning om sosiokulturelt mangfold, med vekt på religionsvitenskap, kulturanalyse og sosialantropologi.

Samtidig som man ser tydelige fellestrekk, kan man spore visse særtrekk ved forskningstradisjonene i de ulike landene. I Finland kan det virke som om beskrivelsen av mangfold synes å ha vært noe mer knyttet til identitetsspørsmål enn til spesifikk tradisjonsbakgrunn (Tirri, 2006). Det er mulig at effekten av sekulariseringen og pluraliseringen på den dominerende lutherske majoriteten er noe av bakgrunnen for at det har vært viktigere å undersøke postmoderne og postsekulær religiøsitet enn å fokusere på religiøse grupper. Samtidig er det også eksempler på gruppefokus, og det gjelder blant annet hvordan indre mangfold gjør seg gjeldende i etablerte religiøse tradisjoner (Niemelä, 2006; Ubani, 2006).

Island har en liten befolkning, og den sentrale religionsdidaktiske forskeren der har i en rekke år vært Gunnar S. Gunnarsson, som har gjort flere studier, også sammen med andre forskere, der målet har vært å kartlegge endringer i religion og livssyn blant islandske barn og unge. Dermed er rimeligvis bildet preget av det Gunnarsson har rettet blikket mot i forskningen sin. Her vektlegger han særlig hvordan økende pluralisering raskt har gjort seg gjeldende i løpet av de siste to tiår. Gunnarsson (2015) viser at for islandske ungdommer er komplekse identitetsforhandlinger del av hverdagen i et samfunn med økt mangfold. Det pekes på hvordan individualisme og pluralisme gjør seg gjeldende innenfor de ulike grupper, ikke minst den kristne majoriteten. Elever erfarer mangfold i hverdagen, og de er selv produkter av mangfold i familiebakgrunnen (Gunnarsson, 2008).

Dette søkelyset på elevmangfold kan via Gunnarssons doktoravhandling fra Stockholm spores tilbake til en tradisjon i nordisk religionsdidaktisk forskning som startet med omfattende forskningsprosjekter i Sverige fra slutten av 1960tallet (Gunnarsson 2009). Skolemyndighetene bestilte den gang forskning om barns og unges livsspørsmål fordi dette var innført som en sentral del av religionsfaget, og de ønsket en sterkere forskningsbasering. Sven Hartman fant gjennom sine intervjuundersøkelser at interessen for livsspørsmål var stor, mens religionsinteressen var mindre (Falkevall, 2010; S. G. Hartman, 1986, 1994; S. G. Hartman \& Torstenson-Ed, 2007; Skeie, 1999). Nyere svensk forskning har lagt mer vekt på å få fram kompleksiteten i religionsmangfoldet, basert på både feltarbeider og intervjuer, men bygger fortsatt på Hartmans arbeider. Det flerkulturelle religions- og livssynsmangfoldet i Sverige i dag beskrives gjerne som preget av både lokal og global kontekst og av interaksjonen mellom barn og unge selv, både i og utenfor skolen (Brömssen, 2003; Kittelmann Flensner, 2015; Risenfors, 2012). Det er også en gryende forskning på religiøse skoler 
som har dokumentert en betydelig indre variasjon, avhengig av kontekst og lærerstil (Berglund, 2010; Berglund \& Larsson, 2007).

I Norge har de store endringene i religionsfaget, både i grunnskolen og lærerutdanningen, ført til økt rekruttering av forskere i religionsdidaktikk, sammenliknet med de andre nordiske landene (Skeie \& Bråten, 2014). Det er betydelig forskningsvirksomhet og en rekke personer med professorkompetanse (Lied, 2006; Skeie, 2017). Dette avspeiles da også i antallet artikler i materialet. Innholdsmessig er mye av norsk religionsdidaktisk forskning orientert mot å dokumentere mangfold, og flere av de norske artiklene i Nordidactica tar opp dette, med resultater som belyser mangfoldets kompleksitet. Nicolaisen (2013b, 2015b) har forsket mye på hindubarn i norsk skole og viser både hvor begrenset kunnskapen er om denne religiøse bakgrunnen og hvordan religion for disse barna inngår i et komplisert samspill med andre kulturelle kategorier. Liknende resultater har også von der Lippe (2011) fått fram, basert på et materiale med ungdommer i norsk skole. Johannessen (2014) har i tillegg vist at mangfold også er relevant for å forstå betydningen av lærernes egen bakgrunn og bakgrunnskunnskap om elevene. Lærere trekker veksler på de personlige erfaringene de har med spesifikke religiøse eller livssynsmessige posisjoner når de skal velge strategier i klasserommet, og de gjorde bruk av interpersonell kunnskap om grupper og lokalsamfunn.

Som nevnt er dansk religionsdidaktisk forskning beskjeden sammenliknet med Sverige, Finland og Norge, og én forsker preger derfor det danske materialet i denne artikkelen. Mette Buchardts (2008) klasseromsforskning har særlig gått inn på skolens produksjon av kunnskap om religiøst mangfold og sosiale forskjeller i religionsfaget. Konkret belyser hun kategorier som muslimskhet, danskhet og kristenhet. Her analyserer hun hvordan posisjonen som muslim skapes av sterke krefter utenfor klasserommet og i sin tur produserer en skolekunnskap som på mange måter lukker elever inne i tilskrevne identiteter. Gjennom analysen blir dermed blir de maktforhold som gjør seg gjeldende i det mangfoldige samfunnet, gjort synlige slik de spilles ut i klasserommet. Buchards forskning avspeiler slik også den polariserte innvandringsdebatten som Danmark har hatt i flere år.

Tross spor av nasjonale særtrekk i forskningsbidragene, kan nye doktoravhandlinger tyde på at forskningen på religiøst og livssynsmessig mangfold gradvis baserer seg på et mer felles bilde av fenomenet, på tvers av land. Helena Zilliachus (2015) kan sies å oppsummere mange av de nevnte aspektene når hun understreker at mangfoldet i dag kan forstås både bredt kulturelt og mer spesifikt som religions- og livssynsmangfold. Hun viser samtidig hvordan postmoderne og fragmenterende elementer bryter opp dette gjennom et interseksjonelt forhold mellom ulike aspekter, som identifisering og posisjonering. Også Karin Kittelmann Flensner (2015) forstår mangfold slik at det omfatter ulik etnisk, kulturell og religiøs posisjonering, men også ulike eleverfaringer i bredere forstand, samt individenes bakgrunn og oppfatninger i 
alminnelighet. Når Johannessen (2015) redegjør for sin forståelse av mangfold, legger også han vekt på økende kompleksitet og interseksjonalitet, med lokale, nasjonale og globale innslag. Han hevder videre at religionsdidaktisk forskning har tilført mangfoldsbegrepet teoretiske og empiriske nyanser ved å vise hvordan religions- og livssynmangfold veves inn i andre aspekter av mangfold.

En sterkt maktkritisk forskning er ikke så er vanlig i nordisk religionsdidaktikk, her er Buchardt (2008) et unntak. Flere av de nevnte forskere peker likevel på at maktforhold gjennomsyrer den mangfoldige skolen, og særlig bidrag fra Sverige har vist at man kan tale om hegemoniske diskurser i religionsundervisningens klasserom. Det mest vanlige synes å være at de sekulære elevene gjennom dette bidrar til å marginalisere elever som posisjonerer seg religiøst slik at deres stemmer ikke blir hørt (Kittelmann Flensner, 2015; Osbeck \& Lied, 2012).

Sammenfattende kan man derfor hevde at forskningens beskrivelse av mangfold ikke er preget av motsetninger, men heller av komplementære perspektiver. Mens enkelte vektlegger religion og livssyn mer spesifikt, så er det mange som på ulike måter kobler dette sammen med andre former for kulturelle og sosiale forskjeller i mer komplekse konstruksjoner. Mye av den tidligere forskningen fokuserte på individuell identitet hos elever med majoritetsbakgrunn, i forlengelsen av oppløsningstendenser i en kristent preget majoritetskultur, mens den forskningen som er dokumentert her, er minst like opptatt av å forstå identitetsprosesser hos elever med minoritetsbakgrunn. Dette kan muligens henge sammen med et skifte i disiplinorientering. Der tidligere forskning var mer utviklingspsykologisk orientert, synes den nyere forskningen å legge mer vekt på sosiologiske og sosialantropologiske perspektiver på mangfold.

Når det gjelder forståelse av mangfoldets dynamikk, finnes en forskningsbasert oppfatning om at religion og livssyn pluralisers, delvis innenfra og delvis utenfra, slik at organiserte religiøse grupper og deres lære ikke alltid er gjennomgående til stede hos deltakerne i disse gruppene. Forskningen på spiritualitet og livsfrågor/livstolkning har reist spørsmål om hvilke nye begreper som kan fange inn endringen som har skjedd i hvordan eksistensielle spørsmål blir stilt og besvart. Man kan betegne dette som individualisering av religion og livssyn, med større vekt på privat religiøsitet og levd religion. Andre deler av forskningen legger større vekt på religionsmangfold som et resultat av migrasjon, og med et noe mer gruppeorientert perspektiv. Det betyr ikke at individperspektivet borte, ettersom ulikheter knyttet til klasse, kjønn, nasjon, etnisitet, språk og kultur bryter opp de religiøse skillelinjene. Man kan si at disse to perspektivene på mangfold trekker i litt ulike retninger, det individorienterte er opptatt av hvordan universelle menneskelige karakteristikker tar seg nye mangfoldige former, mens det gruppeorienterte starter i de synlige ulikhetene. Dette er trekk som kan kjennes igjen i annen forskning på sosiokulturelt mangfold, blant annet i debatten om multikulturalisme. Religionsdidaktikerne, 
som som oftest er lærerutdannere, peker på hvilke utfordringer det skaper for skolen og religionsundervisningen.

\section{Hvilke religionsdidaktiske utfordringer beskrives?}

Forskningsbidragenes beskrivelse av mangfold knytter gjerne an til didaktiske utfordringer, eller så brukes disse utfordringene som argument for relevansen av empiriske undersøkelser av religiøst og kulturelt mangfold. Der er også en rekke bidrag som handler om hvordan man begrepsfester mangfoldet og dets utfordringer, og hvilke teoretiske ressurser man kan gripe til for å finne fram til didaktiske strategier. På den nordiske konferansen i 1999 presenterte Robert Jackson og Geir Skeie forslag til hvordan disse utfordringene kunne formuleres teoretisk (Gunnarsson, 1999). Mange av begrepene til Jackson og andre engelske religionspedagoger er blitt didaktisk felleseie i årene etterpå (representasjon av religion, tolkning av innenfra- og utenfraperspektiver, lære om og av religion, refleksivitet). På den nordiske konferansen i 2009 var Jackson tilbake og rapporterte om de prosesser som skjedde på europeisk nivå med «den religiøse dimensjon i interkulturell pedagogikk» (Jackson 2009). På dette tidspunktet var forskningsbidragene gjennomgående preget av mangfoldsspørsmål når det gjelder hele bredden av didaktiske problemstillinger. Her fantes nternasjonale komparative studier av religionsundervisning, analyse av og forslag til didaktiske tilnærminger og kjønnsperspektiver på mangfold og læremiddelanalyse (Skeie, 2009). På neste konferanse ble samspillet mellom religionsundervisning og politikk, bærekraftig utvikling, medborgerskap og globalisering satt på dagsorden (Sporre \& Mannberg, 2010). Det store bildet er derfor at religionsdidaktiske forskere ikke lengre ser religions- og livssynsmangfold om en særlig type utfordring for undervisning og læring i religionsfagene, men som en sentral del av det mangfold som utgjør konteksten for all fagundervisning.

De teoretiske utfordringer er dels knyttet til hvilke begreper som best fanger inn mangfoldet, og dels til spørsmål om eventuelle fellesmenneskelige forutsetninger for å forstå og tilegne seg kunnskap om religioner og livssyn. I Sverige har dette vært tatt opp i forbindelse med religionsundervisningens mål og innhold (Osbeck \& Skeie, 2014). Gunnarsson (2009) har argumentert for «livstolkning» som et bærende begrep. Dette er da også ofte brukt i svenske og norske bidrag. I Finland, hvor de fleste forskere kommuniserer med nordiske kolleger på engelsk, har «spirituality» vunnet en tilsvarende posisjon i forlengelsen av en internasjonal tradisjon for religionpsykologisk og tverrfaglig orientert forskning på feltet. Den finske forståelsen av «spirituality» er bredere enn «religion» og legger vekt på et holistisk perspektiv på personlig utvikling og posisjonering som ikke er bundet til bestemte religions- eller livssynstradisjoner. Dette har dannet grunnlag for en rekke studier, ikke minst kvantitative (Ubani \& 
Tirri, 2014). I det siste tiåret har innflytelsen fra interkulturell pedagogikk også vært merkbar innenfor spirituality-forskningen og religions- og livssynsmangfold preger nå dagsordenen i flere forskningsbidrag derfra (Ubani, 2017).

Den stadig likere situasjonsforståelsen blant religionsdidaktikere betyr også at organisering og gjennomføring av religions- og livssynsundervisning er blitt et interessefelt på tvers av land. Eksempelvis har økningen i antall muslimer i Finland de siste ti årene gitt forskning som belyser de utfordringer dette gir for den modellen man har valgt for religionsundervisning (Arto Kallioniemi \& Mia Matilainen, 2011). Dette illustrerer også at mangfoldet gjerne først fanges opp av elever og lærere, deretter begynner man å se tegn til endring av klasseromspraksisen, og deretter i læreplaner. Selv om forskningen har begynt å bearbeide dette teoretisk og empirisk, så handler det fortsatt om å identifisere problemområder og å belyse utfordringer i skolen (Gunnarsson, 2017). Samtidig legger utdanningspolitikken premisser for forskningsfokuset gjennom sin vekt på læring av fagstoff. Dette kan gå ut over vilkårene for utforsking av de faktiske mangfoldsutfordringene, som ikke alltid handler om tilegning av fagstoff (Buchardt 2017).

I alle de nordiske landene framstår religionsundervisning som et politisk følsomt felt. Både historiske og komparative studier peker på hvordan mangfold har vært håndtert de i ulike landene, og hvordan det er mulig å lære av sammenliknende studier (Bråten, 2015b; Buchardt, 2015; Duesund, 2013; Kjærgaard, 2015). På tvers av ulike modeller oppfattes mange av utfordringene som felles og internasjonale. Bidragene viser spenninger mellom universelle verdier som er nedfelt i læreplanene (f.eks. menneskerettighetene), nasjonale verdier knyttet til majoritetsbefolkningen (f.eks. kristendommen) og mer kontekstbetingede hensyn til individer og grupper (f.eks. nasjonale, kulturelle og religiøse minoriteter). I flere av landene har man også sett kritisk på hvordan religionsdidaktikken kan ha spilt sammen med ulike kulturstrømninger. Et eksempel på dette er livsfilosofiens plass i dansk religionsundervisning og hvordan denne, tross sin allmennmenneskelige utforming i møte med mangfoldet, har vist seg å være sterkt preget av kristendom (Bøwadt, 2009).

Noen bidrag viser at mangfoldsutfordringer med fordel kan ses på tvers av fag. En artikkel fra Finland peker i så måte på muligheter og utfordringer ved å ta opp verdispørsmål i flere fag, gjennom et digitalt prosjekt som retter søkelyset mot «den arabiske våren» (Björkgren, Gullberg, \& Hilli, 2014). I en dansk artikkel drøftes religion som del av interkulturelle utfordringer på tvers av fag (Hobel, 2013). I begge tilfeller pekes det på betydningen av å tilegne seg metaperspektiver, og at dette er en viktig, men krevende kompetanse. Dominerende diskurser om mangfold oppdages og problematiseres først når man kan se at det finnes alternative diskurser og drøfte hva diskursene er uttrykk for, både kunnskapsteoretisk og etisk, i forbindelse med for eksempel kjønn, klasse, etnisitet, politikk eller religion. I tillegg til at mangfoldet oppfattes som 
en tverrfaglig utfordring, der religionsdidaktikerne har spesielt gode forutsetninger for å bidra, har det også kommet forskning som peker på at elementer av religion og livssyn kan spores i deler av skolens virksomhet, der det tradisjonelt ikke har vært kjent. Dette gjelder blant annet bruk av yoga, mindfulness og andre sosioemosjonelle programmer som berører elevers hverdagsliv og helse, i «livskunskap» i Sverige og på Island (Brömssen, 2013b; Gunnarsson et al., 2015). Disse utviklingstrekkene, og den sterke rollen som helseperspektivet har i svensk skole, er interessante med tanke på den vekt som folkehelse og livsmestring er tenkt å ha i kommende norske læreplaner. Foreløpig er det bare spede forsøk på religionsdidaktisk forskning som tar opp dette i Norge, men dette aspektet av religionsmangfold kan bli mer sentralt i årene som kommer (Zetterqvist \& Skeie 2014).

På tross av mange bidrag med skolerelevans, mener jeg det er grunn til å peke på manglende forbindelseslinjer mellom religionsdidaktisk forskning og utvikling av praksis i skolen. En analyse av svensk religionsdidaktisk forskning har vist at avstanden kan bli stor mellom den universitetskontekst der avhandlinger blir til og den skolekontekst der forskningen skal brukes, dersom man ser på lærerutdanningens religionsdidaktiske pensumlitteratur. (Osbeck, 2017). Også fra Norge pekes det på hvor krevende det er å koble forskning sammen med praksis, og at utvikling av læremidler for lærerutdanning eller å sette i gang utviklingsarbeid knyttet til religionsundervisning og mangfold er krevende (Skeie, 2017).

Oppsummerende er det altså klart at religions- og livssynsmangfold er blitt den dominerende kontekstforståelsen i religionsdidaktisk forskning. Dette gjør at man er oppfatt av mangfoldet som utfordring, men mer som samfunnsmessig utfordring i bred forstand enn som en måte å beskrive læreforutsetninger på. Tidligere var det utfordringer knyttet til religionsundervisningens manglende popularitet og relevans i et sekularisert samfunn som dominerte dagsordenen, nå er det mer hvorvidt mangfoldet er tilstrekkelig representert til at undervisningen blir oppfattet som relevant. Dette kan synes å stå i en viss spenning til den vekt på fagkunnskap og læringsmål som preger utdanningspolitikken i alle de nordiske landene.

Til tross for en vending fra psykologiske til de mer samfunnsorienterte vitenskapstradisjoner, viser bidragene fortsatt stor interesse for hvordan enkeltelevene opplevde og oppfattet religions- og livssynsundervisningen. Det tyder på at mangfoldets utfordringer ikke blir sett så mye som kunnskapsmessige og kognitive, men snarere som sosiale og relasjonelle. Selv om flere publikasjoner nevner kunnskap om religioner og livssyn som en viktig kvalifikasjon hos gode religionslærerne, så er det lite oppmerksomhet mot utfordringer knyttet til læring i religionsfagene. Derimot er det blitt avdekket utfordringer knyttet til at elevene ikke kjenner igjen sine egne tradisjoner i skolekunnskapen om religion, og at klasserommet som kunnskapsarena preges av hegemoniske diskurser som favoriserer sekulære livssynsposisjoner. 
Hvilke strategier foreslår forskningen i arbeid med faget i det mangfoldige klasserommet?

Når forskninger ser religions- og livssynsforskjeller som del av brede samfunnsmessige utfordringer, kan det rimeligvis føre til endringer av måten å organisere religionsundervisning på, slik det ble pekt på innledningsvis at de nordiske land har gjort. I avsnittet ovenfor ble det også pekt på at flere forskere har undersøkt organisering og modeller, selv om det ikke alltid har skjedd med sikte på å foreslå bestemte endringer. I de siste årene kan det se ut som om det er i Finland at studier av læreplaner, organisering av religionsundervisning og synspunkter fra lærerstudenter har pekt på flest problemer med den nåværende ordningen (Kallioniemi \& Matilainen, 2011; Ubani et al., 2015; Zilliacus, 2013).

For øvrig er det et gjennomgående inntrykk at den religionsdidaktiske forskningen har sett det mangfoldige klasserommet som en viktig, men krevende didaktisk arena. Flere av forskningsbidragene understreker at forskjeller bør respekteres og ivaretas, samtidig som problemene med å realisere dette ikke undervurderes. Blant annet pekes det på faren for strukturell diskriminering og at det er viktig å styrke samhold i klassen ved aktivt å inkludere elever med migrantbakgrunn (Zilliacus, 2014). Det er også et inntrykk at et elevorientert perspektiv ser ut til å være mest framtredende, og at religionsundervisning ses som en støtte for enkeltelevers pågående og mangfoldige livstolkningsprosesser (Gunnarsson, 2015).

Til tross for at utdanningspolitikken lenge har lagt stor vekt på læringsutbytte, er det få bidrag i materialet som undersøker læring i fag. Osbeck antyder kanskje en forklaring på dette i sin analyse av religionsfaget i Sverige, som hun mener er preget av overordnede og verdiorienterte målsettinger. Selv om dette kan være viktig for å sikre et godt læringsmiljø, så blir det vanskelig å få tak i hva kunnskap om læringsmål innebærer (Osbeck, 2014). Dette inntrykket bekreftes indirekte gjennom flere andre artikler, slik som Torsten Hyléns drøfting av hvordan en essensialistisk forståelse av religionsbegrepet blir både faglig og didaktisk problematisk i en mangfoldssituasjon, og at dette kan utfordres i klasserommet gjennom arbeidsmåter som utfordrer stereotypiske forestillinger (Hylén, 2012). Kittelman Flensner (2015) har vist at klasserommet ofte preges av en sekularistisk posisjon og at lærere kan forsterke denne gjennom overdreven vekt på nøytralitet og objektivitet. I stedet kunne denne posisjonen betraktes og håndteres som en posisjon blant flere og motvirke en «vi»-og-«dem»-tenkning. Hun hevder også at tematisk og begrepsorientert undervisning synes å svekke et sekularistisk hegemoni, mens tradisjonell undervisning med vekt på verdensreligioner ser ut til å forsterke det.

En generell innsikt som den aktuelle forskningen både implisitt og eksplisitt uttrykker, er at elevenes religions- og livssynsbakgrunn må få konsekvenser for hvordan de ulike religioner og livssyn blir presentert i undervisningen, men at dette ikke alltid skjer (Nicolaisen 2015). Dette innebærer en rekke didaktiske 
valg som læreren må ta i klasserommet, og flere peker på at kunnskap om elevene er viktig for å kunne gjøre gode beslutninger (Westerberg, 2006). I tråd med dette pekes det på faktorer som bestemmer læreres mulighet og evne til å utvikle og ta i bruk kulturkompetanse, blant annet egen biografi og erfaringer, nasjonal og regional mentalitet, men også den begrensede mulighet for å dele erfaringer med hverandre og slik utvikle praksis. Johannessen $(2014,2015)$ har drøftet dette, og hevder at lærere behøver en faglig opplyst og relevant interpersonlig kunnskap om elever og deres relasjoner til hverandre, kunnskap om lokal kontekst og verdibaserte beslutninger om didaktiske valg. Johannessens resultater er blitt til på bakgrunn av aksjonsforskning, og denne forskningstradisjonen tas opp av Elisabet Haakedal (2015) som en mulig strategi for å kombinere empiriske og praksisutviklende studier i religionsdidaktikk i årene framover. Hun diskuterer noen aktuelle religionsdidaktiske aksjonsforskningsprosjekter, og hevder at dette kan være en strategi i møte med mangfoldets utfordringer, ved at skolen, lærerutdanningen og forskningen går sammen i et partnerskap omkring praksisutvikling, og på den måten peker på utfordringer og muligheter for policy utvikling og videre forskning.

Et mangfoldsrelatert felt som har kommet tydeligere på forskningens dagsorden de siste årene, er etikkdidaktikk, som tradisjonelt har vært knyttet til religionsfaget, men som peker ut over dette. Franck (2014) er et eksempel som viser hvordan det blir problematisk å gjøre koblingen for tett mellom livssyn og religioner på den ene siden og (en bestemt) etikk. I stedet vil han utvikle en multikulturell og multireligiøs etisk kompetanse som går på tvers av skolens fag, uten at religionsfaget taper sin del av ansvaret for etikkundervisningen.

Et elevorientert fokus er temmelig gjennomgående hos religionsdidaktikerne, og dette blir tydeligere når man nærmer seg spørsmålet etter forskningens bidrag til strategier og praktiske løsninger. Det betyr ikke at det er en ren harmonitenkning om religioner og livssyn. De fleste vektlegger kompleksitet og variasjon innenfor religions- og livssynsgrupper, noe som innebærer at mangfoldet ses som ikke-reduserbart. Likevel er det få forskningsbaserte forslag til endring av undervisning og læring i bestemte retninger, og lite forskning som søker primært etter dette, bortsett fra noen eksempler på aksjonsforskning. Et gjennomgående trekk er en vektlegging av mangfoldet som noe komplekst, påpekning av hvor store utfordringer dette reiser og at disse utfordringer er kontekstuelt betinget, samtidig som man har et positivt og ressursorientert forhold til dette mangfoldet.

\section{Diskusjon}

Den innledende henvisning til Stortingsmelding 20 (2012-2013), fra Norge, pekte på at religions- og livssynsmangfold ble behandlet mer som et spørsmål om skolens formål enn som del av religions- og livssynsfagets innhold. Selv om denne stortingsmeldingen fokuserer på overordnede spørsmål, så preges ikke 
behandlingen av andre fagområder av tilsvarende avstand til fagets kunnskapsinnhold. Fra et religionsdidaktisk perspektiv kan dette ses som problematisk fordi det skaper uklarhet om fagets stoffinnhold og læringsmål.

Et kritisk blikk på nyere religionsdidaktisk forskning ut fra det begrensede materialet i denne artikkelen tyder imidlertid på at forskningen ikke har kommet med så mange bidrag på dette punktet. I stedet kan det se ut som forskningen primært har bidratt til en omfattende empirisk forskning om religions- og livssynsmangfoldet som finnes i skolen og dens kontekst. Forskningen har pekt på at dette ikke alltid er blitt representert i læreplaner og undervisning hvor blant annet ulike maktforhold gjør seg gjeldende. En mulig forklaring på dette kan være knyttet til den sterke elevorienteringen som virker å gjennomsyre det meste av religionsdidaktikken.

Det forskningen har bidratt mye til, er å beskrive hvordan religion og livssyn på komplekse måter veves sammen med andre innslag i barn og unges liv og slik utgjør læreforutsetninger som må tas hensyn til. Det er ikke et harmonisk og idylliserende bilde av mangfoldet som tegnes opp, til tross for at forskningen har en gjennomgående solidarisk holdning til elever og lærere. Selv om de undersøkte bidragene synes å mene at religions- og livssynsmangfold er en ressurs, så underslås ikke problemene med å finne fram til gode didaktiske strategier. Det står imidlertid mye arbeid igjen med å finne fram til hvordan man kan skape mer likeverdig kommunikasjon om faginnholdet på tvers av ulike posisjoner i klasserommet, for eksempel slik dette fanges opp av begrepet «uenighetsfellesskap» (Iversen, 2014). Man kan imidlertid si at forskerne framstår som både mangfoldets voktere, dets kritiske dokumentarister og dets kommunikasjonsarbeidere.

Som en kontrast til mye av det som dominerer i den forskningen som er presentert i materialet, kan omtalen av Bengt-Ove Andreassens forskning i en av artiklene sies å peke i en annen retning enn det elevorienterte (Skeie, 2017). Andreassen har kritisert deler av norsk religionsdidaktikk for å være elevsentrert og terapeutiserende (Andreassen, 2008, 2013). Også andre nordiske forskere har pekt mot religionsvitenskapelig basert kunnskapsformidling som den beste måten å møte utfordringene på (Jensen, 2008, 2011, 2013). Dette er en indikasjon på behovet for å styrke religionsdidaktisk forskning som fokuserer på selve stoffinnholdet i religionsundervisningen og forholdet mellom elevene og stoffet. Dette leder videre til spørsmål om hva som er fruktbart og realistisk som læringsmål i et religionsfag. Dermed blir det viktig å undersøke undervisning, læreprosesser og læringsresultater slik disse kommer til uttrykk i det mangfoldige klasserommet. Ut fra de forsøk som er dokumentert i den undersøkte litteraturen, kan muligens samarbeidsforskning være en vei å gå. Ettersom de fleste religionsdidaktiske forskere befinner seg i lærerutdanningsinstitusjoner, skulle det ligge vel til rette for å organisere dette i samarbeid med skoler hvor lærerstudentene har sin praksis. 
Det er mye forskning som ikke er belyst i denne gjennomgangen, og som kan sies å peke på en del av de problemene og manglene som nettopp ble nevnt. Arbeidet med artikkelen viste også med all tydelighet at religionsdidaktisk forskning nå er blitt så omfattende at det selv for en aktiv forsker er umulig å holde oversikt over alt det som publiseres. Flere av avhandlingene som er omtalt, har bidratt med viktige litteraturstudier, men også her trengs det mer. Både tiden og forskningsproduksjonen synes derfor moden for systematiske oversikter innenfor religionsdidaktikken. Et viktig poeng med slike oversikter er selvsagt at de presenterer en kunnskapsstatus knyttet til spesifikke problemområder. Slik kan de gjøre det mulig å føre en mer opplyst diskusjon om forholdet mellom utdanningspolitikk, forskning og religionslæreres praksis, og dermed bidra til en bedre religionsundervisning.

\section{Om forfatteren}

Geir Skeie is professor of religious education at the University of Stavanger and Stockholm University. His research interests are the theory and practice of religious education and include issues of diversity and the interface between religions, worldviews and society.

Affiliation: University of Stavanger, Department of Cultural Studies and Langauges, 8600 Forus, Norway / Stockholm University, Department of Humanities and Social Sciences Education, SE-106 91 Stockholm, Sweden

E-mail: geir.skeie@uis.no

\section{Referanser}

Algotsson, K.-G. (1975). Från katekestvång till religionsfrihet : debatten om religionsundervisningen i skolan under 1900-talet (Vol. 70). Motala: Raben \& Sjögren.

Andreassen, B.-O. (2008). "Et ordinært fag i særklasse" En analyse av fagdidaktiske perspektiver i innføringsbøker i religionsdidaktikk. PhD Avhandling. Tromsø: Universitetet i Tromsø

Andreassen, B.-O. (2013). Religion Education in Norway: Tension or Harmony between Human Rights and Christian Cultural Heritage? Temenos, 49(2), 137-164.

Berglund, J. (2010). Teaching Islam. Islamic religious Education in Sweden. Münster: Waxmann.

Berglund, J., \& Larsson, G. (Eds.). (2007). Religiösa friskolor i Sverige. Historiska och nutida perspektiv. Lund: Studentlitteratur.

Björkgren, M., Gullberg, T., \& Hilli, C. (2014). Mot en ämnesintegrativ helhetssyn - ett digitalt utvecklingsprojekt i finländsk lärarutbildning. Nordidactica - Journal of Humanities and Social Science Education(2014:1), 170-187.

Björkgren, M., Gullberg, T., \& Hilli, C. (2014). Mot en ämnesintegrativ helhetssyn - ett digitalt utvecklingsprojekt i finländsk lärarutbildning. Nordidactica: Journal of Humanities and Social Science Education(2014:1), 170-187. 
Brömssen, K. v. (2003). Tolkningar, förhandlingar och tystnader : elevers tal om religion i det mångkulturella och postkoloniala rummet. Göteborg: Acta Universitatis Gothoburgensis.

Brömssen, K. v. (2013a). A European declaration of Independence - An Analysis of Discourses from the Extreme. Nordidactica - Journal of Humanitites and Social Science Education(2013:1), 12-33.

Brömssen, K. v. (2013b). Skolan är en lättköpt arena - livskunskap i kritisk belysning. Nordidactica - Journal of Humanitites and Social Science Education(2013:2), 65-92.

Bråten, O. M. H. (2009). A comparative study of religious education in state schools in England and Norway. PhD thesis. Warwick: Warwick University.

Bråten, O. M. H. (2014). Hva er religonspedagogikk? Internasjonale perspektiver på den norske konteksten. Prismet, 65(3), 123-144.

Bråten, O. M. H. (2015a). Research on Religious Education in Nordic Countries: Introduction to Nordidactica 2015:2. Nordidactica - Journal of Humanities and Social Science Education(2015:2), i-viii.

Bråten, O. M. H. (2015b). Should there be wonder and awe? A three-dimensional and four levels comparative methodology used to discuss the "learning from" aspect of English and Norwegian RE. Nordidactica: Journal of Humanities and Social Science Education(2015:2), 1-23.

Buchardt, M. (2008). Identitetspolitik i klasserummet. 'Religion' og 'kultur' som viden og social klassification. Studier i et praktiseret skolefag. Ph.d. afhandling. Købehavn: Det humanistiske fakultet, Københavns Universitet.

Buchardt, M. (2014). Religious Education at Schools in Denmark. In M. Rothgangel, G. Skeie, \& M. Jäggle (Eds.), Religious Education at Schools in Europe. Part 3: Northern Europe (pp. 45-74). Göttingen: V\&R unipress / Vienna University Press.

Buchardt, M. (2015). Cultural Protestantism and Nordic Religious Education: An incision in the historical layers behind the Nordic Welfare state model. Nordidactica: Journal of Humanities and Social Science Education (2015:2), 131-165.

Buchardt, M. (2017). Religious Education research in welfare state Denmark. A historical and institutional perspective on an epistemological discussion. Nordidactica: Journal of Humanities and Social Science Education (2017:1), 49-65.

Bugge, K. E., \& Johannessen, S. (Eds.). (1974). Religionspcedagogiske brydninger. København: Nyt Nordisk Forlag.

Dessingué, A. (2016). Dynamisk kulturarv, kritisk literacy og (fler)kulturforståelse i norsk grunnskole? Nordidactica - Journal of Humanities and Social Science Education (2016:2), 22-46.

Duesund, K. (2013). Is There a Potential for Norway to Learn from the Ethics Education in the Educational System of India? Nordidactica - Journal of Humanities and Social Science Education, 2013:2, 142-164.

Døving, C. A. (2016). Pluralismens voktere - Samarbeidsrådet for tros- og livssynssamfunn som politisk aktør gjennom 20 år. Kirke og kultur, 120(4), 362-385.

Engen, T. O. (1990). Migrasjonsforskning i Norge 1980-1990. En prosjektoversikt. Oslo: Utlendingsdirektoratet.

Engen, T. O. (1993). Migrasjonsforskning i Norge 1985-1993. En prosjektkatalog. Oslo: Norges Forskningsråd.

Falkevall, B. (2010). Livsfrågor och religionskunskap: en belysning av ett centralt begrepp i svensk religionsdidaktik. Dr. avh. Stockholm: Stockholms Universitet.

Franck, O. (2014). Gränsöverskridande värden i icke konfessionell etikundervisning: ämnesidentitet och multidisciplinärt lärande i ämnet religionskunskap. Nordidactica Journal of Humanities and Social Science Education (2014:1), 188-211. 
Gunnarsson, G. J. (2008). "I Don't Believe the Meaning of Life is All That Profound" A study of Icelandic teenagers' life interpretation and values. PhD thesis. Stockholm: Stockholms University.

Gunnarsson, G. J. (2014). Religious Education at Schools in Iceland. In M. Rothgangel, G. Skeie, \& M. Jäggle (Eds.), Religious education at schools in Europe. Part 3: Northern Europe (pp. 127-150). Göttingen: V\&R unipress Vienna University Press.

Gunnarsson, G. J. (2017). From religious homogeneity to secularization, diversity and pluralism. Nordidactica: Journal of Humanities and Social Science Education (2017:1), $1-26$.

Gunnarsson, G. J. (Ed.) (1999). Kundskab og oplevelse. Forelæsninger, præsentation af forskningsrcesultater og forsknignsrapporter fra Nordisk religionspcedagogsik forskerkonference i Varmaland, Island den 11.-15. august 1999. Reykjavik: Islands Pædagogiske Universitet:.

Gunnarsson, G. J., Finnbogason, G. E., Ragnarsdóttir, H., \& Jónsdóttir, H. (2015). Friendship, diversity and fear. Young people's life views and life values in a multicultural society. Nordidactica - Journal of Humanities and Social Science Education (2015:2), 94-113.

Haakedal, E. (2015). Action research and development work in religion and world view education - comparing communities of practice and cooperative networks. Nordidactica: Journal of Humanities and Social Science Education (2015:2), 47-73.

Hartman, S. (2017). Response: On RE research in the Nordic countries - a few notes. Nordidactica: Journal of Humanities and Social Science Education (2017:1), 118-122.

Hartman, S. G. (1986). Barns tankar om livet. Stockholm: Natur och kultur.

Hartman, S. G. (1994). Children's Personal Philosophy of Life. PANORAMA International Journal of Comparative Religious Education and Values, 6(2), 104-128.

Hartman, S. G., \& Torstenson-Ed, T. (2007). Barns tankar om livet (2. utg. ed.). Stockholm: Natur och kultur.

Hobel, P. (2013). When the Entire World is pushed into the Classroom: Reflections on Communication, Interculturalism and Education and on Intercultural Education in the Danish Upper Secondary School. Nordidactica - Journal of Humanitites and Social Science Education, (2013:1), 227-252.

Hylén, T. (2012). Essentialism i religionsundervisningen: Ett religionsdidaktiskt problem. Nordidactica - Journal Of Humanities And Social Science Education (2012:2), 106-137.

Innst. 432 S (2012-2013). Innstilling til Stortinget fra kirke-, utdannings- og forskningskomiteen. Meld. St. 20 (2012-2013) Oslo: Stortinget. https://www.stortinget.no/no/Saker-ogpublikasjoner/Publikasjoner/Innstillinger/Stortinget/2012-2013/inns-201213-432/

Iversen, L. L. (2014). Ueninghetsfellesskap. Blikk på demokratisk samhandling. Oslo: Universitetsforlaget.

Jensen, T. (2008). Religion in Public Schools: A Must for a Secular State. Numen, 55(2-3), 123-150.

Jensen, T. (2011). Why Religious education, as a Matter of Course, ought to be Part of the Public School Curriculum. In L. Franken \& P. Loobuyck (Eds.), Religious Eucation in a Plural, Secularised Society. A Paradigm Shift Münster: Waxmann, 131-149.

Jensen, T. (2013). A Battlefield in the Culture Wars : Religious Education in Danish Elementary School 1989-2011. In A. Jödicke (Ed.), Religious Education, Politics, the State and Society. Württzburg: Ergon Verlag, 25-48.

Johannessen, Ø. L. (2014). “It’s just very natural” - interpersonal knowledge as a didactical device in guided classroom conversations in religious education. Nordidactica - Journal of Humanitites and Social Science Education (2014:2), 51-75. 
Johannessen, Ø. L. (2015). Kulturkompetanse i religionsundervisningen? : en studie av religionslereres arbeid i det mangfoldige klasserommet. (PhD), Universitetet i Stavanger, Stavanger.

Kallioniemi, A., \& Matilainen, M. (2011). Headmasters'Conceptions of the Finnish Religious Education - Solution from the Perspective of Human Rights. Nordidactica - Journal Of Humanities And Social Science Education (2011:2), 1-14.

Kittelmann Flensner, K. (2015). Religious Education in Contemporary Pluralistic Sweden. (PhD), University of Gothenburg, Gothenburgh. Retrieved from http://hdl.handle.net/2077/41110

Kjærgaard, K. (2015). Religious Education, Identity and Nation Building - the Case of Greenland. Nordidactica: Journal of Humanities and Social Science Education (2015:2), 114-130.

Krupka, B. (2017). Response: the diversity of RE as a research field and the social function of religion as a moral negotiation ground. Nordidactica: Journal of Humanities and Social Science Education (2017:1), 109-117.

Lied, S. (2006). Norsk religionspedagogisk forskning 1985-2005. Norsk Teologisk Tidsskrift, 107(3), 163-195.

Lied, S., \& Bakke, S. U. (2013). Canon and archive in messages from Oslo Cathedral Square in the aftermath of July 22nd 2011. Nordidactica - Journal of Humanitites and Social Science Education (2013:1),34-56.

Lippe, M. S. v. d. (2011). Reality Can Bite: Perspectives of Young People on the Role of Religion in Their World. Nordidactica - Journal of Humanitites and Social Science Education, (2011:2), 15-34.

Nicolaisen, T. (2013). Pluralistisk religionsundervisning og egengjøring som ideal. Hva kan vi lære av erfaringene til barn med hindubakgrunn? Nordidactica - Journal of Humanities and Social Science Education (2013:2), 115-141.

Nicolaisen, T. (2015). Elevers komplekse identitetskrav som utfordring i religions- og livssynsundervisning. Nordidactica - Journal of Humanities and Social Science Education (2015:1), 1-21.

Nielsen, M.-B. O. (2012). Demokratikompetanse for den digitale offentliheten og det diskursive demokratiet? En analyse av skolens læreplaner i lys av utfordringene fra 22. juli. . In T. Solhaug, K. Børhaug, O. S. Stugu, \& O. K. Haualøkken (Eds.), Skolen, nasjonen og medborgaren Trondheim: Tapir akademisk forlag, 127-154.

Niemelä, K. (2006). Does Religious Upbringing Matter? . In K. Tirri (Ed.), Religion, Spirituality and Identity. Bern: Peter Lang, 153-172.

Nyléhn, J., \& Biseth, H. (2015). En utvidelse av begrepet «mangfold». Norsk Pedagogisk Tidsskrift, 99(3-4), 307-318.

Ongstad, S. (2012). Fra kunnskap, via kontekst, kjerne og komparasjon til kommunikasjon. En fagdidaktisk utviklingslinje? Nordidactica - Journal Of Humanities And Social Science Education (2012:1), 1-25.

Ongstad, S. (2017). Pedagogisk + fagdidaktisk forskning = utdanningsforskning? Norsk Pedagogisk Tidsskrift, 101(1), 68-79.

Ongstad, S. (Ed.) (2006). Fag og didaktikk i læererutdanning. Kunnskap i grenseland. Oslo: Universitetsforlaget.

Osbeck, C. (2014). Conditions for Teaching and Learning in Religious Education (RE): Perspectives of Teachers and Pupils at the Beginning of the 6th Grade in Sweden. Nordidactica: Journal of Humanities and Social Science Education (2014:2), 76-96.

Osbeck, C. (2017). Examples of knowledge contributions in Swedish RE - A discussion of disciplines as frames for knowledge re/production. Nordidactica: Journal of Humanities and Social Science Education (2017:1), 66-86. 
Osbeck, C., \& Buchardt, M. (2017). Editorial Nordidactica 2017:1: Epistemologies of Religious Education Research in the Nordic Welfare states. Nordidactica: Journal of Humanities and Social Science Education (2017:1), I-VII.

Osbeck, C., \& Lied, S. (2012). Hegemonic speech genres of classrooms and their imporance for RE learning. British Journal of Religious Education, 34(2), 155-168.

Osbeck, C., \& Skeie, G. (2014). Religious Education at Schools in Sweden. In M. Rothgangel, M. Jäggle, \& G. Skeie (Eds.), Religious education at schools in Europe. Part 3: Northern Europe. Göttingen: V\&R unipress Vienna University Press, 231-260.

Risenfors, S. (2012). Gymnasieungdomars livstolkande. Göteborg: Göteborgs Universitet Acta Universitatis Gothoburgensis

Rothgangel, M., Jackson, R., Jäggle, M., \& Skeie, G. (2014). Preface in Religious Education at Schools in Europe Religious Education at Schools in Europe. Part 3: Northern Europe (pp. 269): Vandenhoeck \& Ruprecht.

Rothgangel, M., Skeie, G., \& Jäggle, M. (Eds.). (2014). Religious education at schools in Europe. Part 3: Northern Europe. Göttingen: V\&R unipress Vienna University Press.

Schihalejev, O., Sporre, K., Skeie, G., Gunnarsson, G. J., \& Räsänen, A. (2016). Shifting borders in religous education. Theological Journal Publicaton of the Estonian Theological Society, 69, 3-8.

Skeie, G. (1999). Empirisk livsåskådningsforskning og dens relevans for religionspedagogisk forskning. Tidsskrift for Kirke, Religion og Samfunn, 12(2), 149-168.

Skeie, G. (2017). Where is Norwegian religious education research heading? A discussion based on two dissertations. Nordidactica: Journal of Humanities and Social Science Education (2017:1), 27-48.

Skeie, G. (Ed.) (2009). Religious diversity and education. Nordic perspectives. Münster: Waxmann.

Skeie, G., \& Bråten, O. M. H. (2014). Religious Education at Schools in Norway. In M. Rothgangel, M. Jäggle, \& G. Skeie (Eds.), Religious education at schools in Europe. Part 3: Northern Europe). Göttingen: V\&R unipress Vienna University Press, 203-230.

Skinningsrud, T. (2012). Fra reformasjonen til mellomkrigstiden : framveksten av det norske utdanningssystemet. (PhD), Universitetet i Tromsø, Tromsø.

Sporre, K., \& Mannberg, J. (Eds.). (2010). Values, Religions and Education in Changing Societies. Dordrecht: Springer.

Stortingsmelding 20 (2012-1013) På rett vei. Kvalitet og mangfold i fellesskolen. Oslo: Kunnskapsdepartementet. https://www.regjeringen.no/no/dokumenter/meld-st-2020122013/id717308/

Tirri, K. (Ed.) (2006). Religion, Spirituality and Identity. Bern: Peter Lang.

Ubani, M. (2006). What Makes Life Spiritual? In K. Tirri (Ed.), Religion, Spirituality and Identity). Bern: Peter Lang, 119-134.

Ubani, M. (2017). Contextualising the contribution of RE scholarly communities to the development of RE didactics in Finland over recent decades. Nordidactica: Journal of Humanities and Social Science Education (2017:1), 87-108.

Ubani, M., Kallioniemi, A., \& Poulter, S. (2015). Finnish Class Student Teachers' Perceptions of Religious Education. Nordidactica: Journal of Humanities and Social Science Education (2015:2), 74-93.

Ubani, M., \& Tirri, K. (2014). Religious Education at Schools in Finland. In M. Rothgangel, G. Skeie, \& M. Jäggle (Eds.), Religious education at schools in Europe. Part 3: Northern Europe. Göttingen: V\&R Unipress /Vienna University Press, 105-126.

Vestøl, J. M. (2016). On teaching what cannot be said: Reflections on the role of the unsayable in religious education. Nordidactica - Journal of Humanities and Social Science Education (2016:2), 1-21. 
Westerberg, B. (2006). To Teach Is to Choose. In K. Tirri (Ed.), Religion, Spirituality and Identity). Bern: Peter Lang, 173-188.

Westrheim, K., \& Hagatun, K. (2015). Hva betyr «kompetanse for mangfold» i utdanningssystemet? - Et kritisk perspektiv på mangfolddiskursen. Norsk Pedagogisk Tidsskrift, 99(3), 168-180.

Westrheim, K., \& Tolo, A. (Eds.). (2014). Kompetanse for mangfold : om skolens utfordringer i det flerkulturelle Norge. Bergen: Fagbokforlaget.

Zetterqvist, K. G., \& Skeie, G. (2014). Religion i skolen: her, der og hvor-som-helst? Norsk Pedagogisk Tidsskrift, 98(5), 304-315.

Zilliacus, H. (2013). The Inclusion of Minority Religious Education in the Finnish Comprehensive School: A Teacher and Teacher Coordinator Perspective. Nordidactica: Journal of Humanities and Social Science Education. (2013:2), 93-114.

Zilliacus, H. (2014). Supporting Students Identities and Inclusion in Minority Religigous and Secular Ethics Education: A Study on Plurality in Finnish Comprehensive School. (PhD), University of Helsinki, Helsinki.

Østberg, S. (1998). Religionshistorie og religionsdidaktikk. In I. M. Ruud \& S. Hjelde (Eds.), Enhet i mangfold? 100 år med religionshistorie i Norge. Oslo: Tano Aschehoug, 239-261. Ålvik, T. (1974). Om fagdidaktikk : et nøkkelbegrep i nyere lærerutdanning. Pedagogen (1/1974), 3-18. 